\title{
Money Demand and Equity Markets
}

\author{
Seth B. Carpenter ${ }^{\square_{\text {and Joe Lange }}}$ \\ Board of Governors of the Federal Reserve System \\ and \\ Cornerstone Research
}

October 2002

\begin{abstract}
Money demand in part reflects a portfolio decision. As equities have become a significant store of household wealth, it seems plausible that variations in equity markets could affect money demand. We re-specify a standard money demand equation to include stock market volatility and revisions to analyst earnings projections. We find that these equity market variables are statistically significant and reduce the errors from money demand models.
\end{abstract}

\footnotetext{
${ }^{1}$ The views expressed are those of the authors and not necessarily those of the Federal Reserve System or other members of the staff. We would like to thank Sherry Edwards, Brian Madigan, and William Whitesell for helpful discussion and Fernanda Iturbe and Dennis Dong for research assistance. Any errors are our own.
} 


\section{Introduction}

The money demand literature has a long and checkered history. The breakdown of previously stable relationships has led to re-specification of models throughout the post-war period. Notable examples are the "case of the missing money" in the 1970s and the under-prediction of money in the 1980s. Nevertheless, policy makers continue to pay attention to monetary aggregates and the charter of the European Central Bank lists money as one of the pillars of its monetary policy.

A stable money demand function has long been sought after because it can be very useful for explaining, and even predicting, the behavior of other aspects of the macro-economy. In traditional formulations, money demand is a function of a scale variable, like nominal GDP, and the opportunity cost of holding money. If 1.) the elasticity with respect to the opportunity cost is known, and 2.) the relationship between money with GDP is stable, then the observation of money data, which tend to be relatively high frequency, can help to predict nominal output, which is observed at a lower frequency. While both of those conditions are important, it is the second that is most often called into question.

Conceptually, money is an asset with a particular set of characteristics, most notably its liquidity. Like other financial assets, demand for money is part of a portfolio allocation decision, in which an agent's wealth is distributed among competing assets based on each asset's relative benefits (see e.g., Tobin 1969). To a certain extent, agents are willing to give up the higher return of alternative assets in order to receive the benefit of liquidity that money provides. Thus, standard money demand equations include an interest rate or interest rate spread to measure the opportunity cost of holding non-interest 
earning money. Typically the assumed alternative asset used to measure the opportunity cost of holding money is a risk-free instrument, such as a Treasury security, though this is often viewed as a proxy for all substitute assets for money.

Through time, the stock market has become a more important store of wealth for households. Growth and innovations in mutual fund industry and the emergence of internet trading have reduced transaction costs and thus increased the substitutability between equities and money. Bertaut and Starr-McCluer (2000) explore the evolution of household portfolios. Using survey data, they report that the fraction of households that own bank accounts has remained steady, between 87 and 90 percent from 1983 through 1998. In contrast, only 4-1/2 percent of households owned mutual funds in 1983, compared to 10-1/2 percent in 1992 and 16-1/2 percent in 1998. In terms of the fraction of households' portfolios, Bertaut and Starr-McCluer report that bank accounts declined from 8-1/4 percent of total assets in 1983 to 6-1/4 percent in 1998. Wealth in mutual funds increased from about one percent of total assets in 1983 to 5 percent in 1998; mutual funds represent almost as large a share of households' assets as bank deposits, and direct ownership of individual stocks makes up another 10 percent of total assets.

In this paper we introduce two indicators of equity market conditions, the volatility in equity prices and revisions to analysts' earnings expectations, into a money demand model. Assuming that agents are risk-averse, volatility in the value of an asset tends to make that asset less attractive, all other things constant, and thus could push investors into safer alternative assets. Similarly, equity prices are a function of the discounted future earnings of the company, so changes in earnings forecasts represent changes in the opportunity cost of holding money, albeit along a different dimension than 
the standard risk-free interest rate trade-off.

We find that these equity market variables are statistically and economically significant in the money demand equation over the period from the early 1990s to the present. Inclusion of these variables tightens the estimated money demand relationship. Further, what limited out-of-sample prediction we can perform suggests that these variables ought not be ignored in any investigation of money demand.

The next section of the paper reviews a small part of the vast literature on money demand. The history of this literature helps to explain our choices in modeling, both in specification and estimation technique. Next, we turn to the estimation of the equity markets model itself. We present the econometric results of our estimation, compare them to a baseline money demand model, evaluate the magnitude of the contribution of equity market variables, and present some out-of-sample results.

\section{Background}

The literature on money demand is too vast to be completely summarized in this paper, so we focus on empirical models of money demand. Our baseline model is the

standard Federal Reserve Board staff model, first elaborated in Moore, Porter, and Small (1990), hereafter MPS. This section reviews some other previous work to motivate our modeling choice, first and foremost of which is the choice of a measure of money.

In their review article, Goldfeld and Sichel (1990) cover much of the previous literature on money demand models. Each of these models is based on M1, a narrow definition of money including only currency, travelers' checks, and checkable deposits. As the authors point out, the development of NOW accounts in the early 1980s 
introduced interest-bearing assets into that monetary aggregate, making it difficult to construct a narrow measure of money that was linked solely to transaction demand. Further, the development of money market deposit accounts (MMDA) and money market mutual funds (MMMF), the latter giving fairly easy access to checking, blurred the distinction between M1 and broader definitions of money.

To complicate matters further, in the mid-1990s commercial banks instituted retail "sweep" accounts, which temporarily transfer funds from non-interest bearing checking accounts to savings accounts at a high frequency, thereby paying customers a return on checkable deposits and reducing the bank's reservable liabilities, distorting narrow measures of money. To avoid these types of complications the Conference Aggregate model uses M2 as the monetary aggregate. This choice is even less contentious when money demand is thought of as a portfolio choice, allocating wealth between money (a very liquid asset) and other assets, presumably with less liquidity. In particular, the development of the M2 aggregate was in part motivated by a desire to have a monetary aggregate that maintained a stable relationship with interest rates. Very narrow measures of money tend to be highly sensitive to changes in interest rates and are further undermined by the institutional changes mentioned above.

The choice of model formulation and estimation method is another significant consideration. Until the widespread use of cointegrating techniques, most money demand models were estimated either in log-levels or as log-differences. One of the early quarterly specifications, laid out by Goldfeld (1973), was in log-levels and became a standard formulation. However, the problem of regressions involving non-stationary variables is now well known, and Johansen and Juselius (1990) presented an early 
application of cointegration to a money demand framework.

As Engle and Granger (1989) point out, cointegration and error-correction models are not truly distinct models. Because most theoretical models of money demand, whether based on transactions demand or portfolio choice, imply an equilibrium in levels, it is important to capture this relationship in the specification. However, short-run dynamics of the money demand functions are important as well. Hence, we follow the Conference Aggregate model and use an error-correction model to capture the long-run, cointegrating relationship between money and the driving variables, while allowing a rich array of short-run dynamics.

The choice of a scale variable in money demand equations has also received a good deal of attention. Goldfeld and Sichel (1990) and Judd and Scadding (1982) each review the various choices employed. Income (previously defined as GNP, now as GDP) is the most common choice, however many arguments have been made in favor of wealth or permanent income. Bomberger (1992) found that for cross-section data, both wealth and income are statistically significant, while in time-series, the collinearity often renders one of the variables insignificant, depending on the particular specification. Unfortunately, wealth is observed much less frequently and with larger revisions than income, making it less useful as a variable for policy analysis.

Consumption has been proposed as a proxy for permanent income. Elyasiani and Nasseh (1994) test whether income or consumption is a more appropriate variable. They find consumption to be a better fit for models with M1, but do not favor income or consumption for models of M2. The Conference Aggregate model employs nominal GDP in the long-run equilibrium relationship but uses consumption in the dynamics. This 
specification can be thought of as a compromise, and MPS point out that the choice of consumption in the dynamics was made to improve the model's fit. We feel comfortable in using both nominal income and consumption, following MPS, because it seems plausible that consumption is more "money-intensive" than other components of GDP, such as investment spending.

As Judd and Scadding (1982) and Goldfeld and Sichel (1990) document, researchers have used a variety of opportunity cost measures. For studies using M1 as the monetary variable, the savings deposit rate had been used, but since savings deposits are included in M2, this choice would be inappropriate for our purposes. Consensus has settled on a short-term, risk-free rate, with the three-month Treasury bill rate the most common choice. As MPS point out, however, simply using an alternate interest rate could lead to an identification bias if the interest rate is in part determined by money demand. Therefore, MPS use the spread between the rate on M2 deposits and the rate on the three-month Treasury bill. The M2 own rate is the deposit share weighted average of returns on the components of $\mathrm{M} 2$, with returns on currency and demand deposits set at zero.

\section{Estimation}

Although we build on the MPS framework, we estimate our model over a different sample period. Like the so-called "missing money" episode for M1, models of M2 over-predicted notably in the early 1990s, during a period referred to as the velocity shift period (Orphanides and Porter (1998), Duca (2000), and Lown, Peristiani, and Robinson (1999)). Chart 1 depicts the time series relationship between the velocity of 
M2 (nominal GDP/M2) and the opportunity cost of holding M2. As the chart shows, for much of the history of the two series, the variables tracked each other reasonably well. Higher opportunity costs resulted in a higher velocity, or a lower level of M2 conditional on GDP.

Around 1990, this relationship seems to break down as the opportunity cost fell and remained quite low while velocity increased. Although there are some economic arguments to explain this period (see Lown, Peristiani, and Robinson (1999)), estimating models across this period econometrically is problematic and relies on essentially ad hoc fixes. Moreover, the importance of equity markets in household portfolios has been increasing through time and it seems plausible that the full substitutability across markets did not exist until the 1990s. As documented above, the fraction of households holding mutual funds and equities increased dramatically from the 1980s to the 1990s. Thus, testing for a significant effect of stock market variables on money demand prior to the 1990s seems less fruitful, particularly as it would involve dealing with the velocity shift period.

The Conference Aggregate model for M2 is an error-correction model with a long-run equilibrium relationship between the natural $\log$ of velocity of M2 and natural $\log$ of opportunity cost. Here, $y$ represents nominal GDP, $m$ represents M2, and $O C$ represents the opportunity cost of holding M2.

$$
\ln y_{t}-\ln m_{t}=\alpha_{0}+\alpha_{1} \ln O C_{t}+e_{t}
$$

The model imposes a unitary elasticity of income by making velocity the left-hand side of 
the equation. MPS test this restriction and fail to reject it. Because we are most interested in the supplemental effects of the equity market variables, and not a wholesale re-specification of a money demand model, we maintain this structure without testing it over our more recent sample period. In addition, MPS use an approximation to the natural $\log$ for the opportunity cost. When the actual opportunity cost is below 0.5 , they replace it with a Taylor-series approximation to avoid problems with numbers close to zero. Our sample does not have this problem, as the opportunity cost never dips that low, so the simple natural log of the opportunity cost is used.

The above equation describes the long-run equilibrium of the money demand function. The quarterly log change in M2 is a function of the previous period's deviation from this long-run relationship (the error correction) as well as one lag of the dependent variable, contemporaneous log changes in opportunity cost, and contemporaneous and two lagged changes in private consumption expenditure (pce):

$$
\begin{aligned}
& \Delta \ln m_{t}=\beta_{1} e_{t-1}+\beta_{2} \Delta \ln O C_{t}+\beta_{3} \Delta \ln m_{t-1}+\beta_{4} \Delta \ln p c e_{t} \\
& +\beta_{5} \Delta \ln p c e_{t-1}+\left(1-\beta_{3}-\beta_{4}-\beta_{5}\right) \Delta \ln p c e_{t-2}+\varepsilon_{t}
\end{aligned}
$$

The restricted coefficient on the second lag of consumption expenditure forces the assumed long-run unitary elasticity to hold. Specifying the long-run and short-run mechanics of the system in such a way leads to increased flexibility over single-equation methods. The relationship in levels is maintained by the error-correction mechanism; however the coefficients in the dynamic equation allow changes in either the scale variable or the opportunity cost to have differential rates of impact on the growth of money.

As described above, the opportunity cost is based on the spread of the M2 own 
rate to the three-month Treasury bill rate. However, households have had increased access to other financial assets over time. In particular, through the 1990s, more and more households have owned equities, either directly or through mutual funds holdings. This represents a margin of substitution, perhaps not captured by the standard opportunity cost measure. To proxy for this equity-related opportunity cost, we use analysts forecasts of calendar-year earnings for each company in the S\&P 500 from the IBES database. Monthly revisions to the forecasts for the current and the upcoming calendar years are appropriately weighted to capture the implied change over the coming twelve months. Although these weighted estimates carry the assumption of constant earnings within each calendar year, because we are looking at revisions rather than levels, seasonality-related distortions should be minimal. The monthly revisions are converted to quarterly averages for inclusion in the money demand equations. These forecasts presumably capture changes in the market's perception of the expected return to equities.

Chart 2 plots these changes against forecast errors from the Conference Aggregate model. As can be seen, the revisions to the earnings forecasts tend to track the forecast errors reasonably well, particularly in late 1998 and from 2000 to 2001 . The historically higher return in the equities market is usually explained as a premium in exchange for the risk of holding these assets. In most portfolio theory, assets are balanced in terms or risk versus reward. Because monetary assets tend to be essentially riskless (ignoring inflation risk) the risk of a substitute asset ought to have a significant impact on the relative share of the portfolio allocated to money, assuming a risk-averse agent. Chart 3 plots the forecast errors from the standard money demand model and an index of implied volatility from the S\&P 100. This index is derived by essentially inverting an options pricing 
model and inferring what level of volatility is consistent with the observed prices. We have also used measures based on ex post realized volatility, and the two series (implied vs. realized) seem to track each other rather well.

The volatility index $(\mathrm{vol})$ is included into the equilibrium equation because the risk of the alternate asset should influence the equilibrium quantity of money in a portfolio.

$$
\ln y_{t}-\ln m_{t}=\alpha_{0}+\alpha_{1} \ln O C_{t}+\alpha_{2} v o l_{t}+e_{t}
$$

A greater riskiness in equities, that is higher volatility, should be expected to induce a greater demand for money. That is to say, if the volatility in the stock market were to permanently rise, all other things equal, one would expect the equilibrium level of money balances to rise as well as portfolios were adjusted away from the riskier asset, implying a negative coefficient on the volatility variable, $\alpha_{2}$.

The revision to analysts earnings forecasts $(\mathrm{rev})$ is put into the dynamics of the model.

$$
\begin{aligned}
& \Delta \ln m_{t}=\beta_{1} e_{t-1}+\beta_{2} \Delta \ln O C_{t}+\beta_{3} \Delta \ln m_{t-1}+\beta_{4} \Delta \ln p c e_{t} \\
& +\beta_{5} \Delta \ln p c e_{t-1}+\left(1-\beta_{3}-\beta_{4}-\beta_{5}\right) \Delta \ln p c e_{t-2}+\beta_{6} r e v_{t}+\varepsilon_{t}
\end{aligned}
$$

Because these revisions represent a change instead of the level, they are not appropriate in the equilibrium equation. One would expect a priori that a positive revision to earnings expectations would cause a lower rate of growth of money. A greater expected 
return in a competing asset should reduce the demand for money, implying a negative coefficient on the revisions variable $\beta_{6}$.

\section{Estimation Results}

Table 1 presents parameter estimates for different models and different sample periods. To allow for some out-of-sample testing, we estimated the models over the shorter 1995:4 to 2000:3 sample period in addition to the period 1995:4 to 2002:1. Because interest rates fell dramatically in 2001, the longer period yields better identification of the opportunity cost coefficient. Columns (1) to (3) report the coefficients from the Conference Aggregate model. Columns (4) and (5) present the coefficients from the our Equity Markets or EM model.

Consider first the estimated coefficient on the opportunity cost in the equilibrium equation. We take the 1964:1 to 1988:4 Conference Aggregate model—column (1)— to be our baseline for comparison. The long-run elasticity of money demand with respect to opportunity cost is 0.56 . The same model estimated over the 1995:4 to 2000:3 samplecolumn (2) - period has a much larger coefficient, but is poorly estimated with a standard error ten times the size as the original. As suspected, when the sample period includes the large change in interest rates in 2001 , the standard error is greatly reduced and the magnitude of the coefficient is much closer to the original specification, column (3).

The EM model shows a similar pattern for the two samples. In particular, the estimated long-run elasticity with respect to opportunity cost over the longer samplecolumn (5) - is essentially equal to that of the original Conference Aggregate model. This result gives us a bit of confidence that the original specification is still plausible and 
also allows us to examine the effect of the additional variables.

There is, however, a major difference between the old 1964:1 to 1988:4 sample and the post-velocity shift sample in terms of the dynamic equation. Relative to the original formulation, the error-correction coefficient is somewhat smaller in the reestimated Conference Aggregate model and cut in half in the EM model. However, the short-run coefficients on the changes in interest rate and scale variables are all higher in the latter sample periods, resulting in faster overall response of money demand to changes in these variables. Combined with the smaller magnitude of the coefficient on the lagged dependent variable, the smaller error-correction coefficient implies a slower response of money demand to a shock to the level of money than was previously the case.

Focusing on column (5) of the table, the coefficients on each of the equity market variables is statistically significant at the five percent level. Consider the equity market volatility variable. Recalling the structure of the estimation equation, the negative sign implies that an increase in volatility causes an increase in equilibrium money holdings. This is consistent with the theoretical prediction that increased risk in an asset (say, equities) should boost demand for alternative assets, like money. To quantify the effect, the average level of the volatility index over the estimation period was 24.4 percent. An increase in volatility of ten percentage points would imply an increase in equilibrium money balances of about two percent. While that is not a huge effect, it is statistically significant, and we will later decompose money growth into contributions from each of the variables over recent quarters.

The revisions variable is also statistically significant at the five percent level. The negative sign implies that a positive change to forecasted earnings per share would cause 
a reduction in the growth rate of $\mathrm{M} 2$. In essence, this result implies that a positive innovation to expected return in the equity market would divert funds from M2 assets toward equity assets. An increase of one percent in the earnings per share forecasts would result in a 0.2 percentage point reduction in the growth rate of money.

\section{Decomposition}

Table 2 presents results of the estimated model relative to actual M2 growth, as well as decomposing the growth of money into the contributions of the driving variables all at an annual frequency. Unsurprisingly, and perhaps reassuringly, the majority of the movement in M2 is still attributed to interest rates and scale variables. Earnings revisions - column (6) — caused M2 growth of one percentage point or more. This effect is roughly the same magnitude as the interest rate effects, shown in column (4). In fact, in 2001, when earnings forecasts were being ratcheted down dramatically, the growth rate of M2 was increased substantially. Volatility—column (7)—has a smaller, but nonnegligible effect on money. Column (3) provides some idea of the fit of the model. Although these results are in-sample, the model does not miss by more than threequarters of a percentage point.

\section{Out of Sample Performance}

Table 3 presents quarterly results from the EM model estimated over the 1995:4 to 2000:3 sample period to allow us to look at the out-of-sample properties. As can be seen, in most of the out-of-sample quarters, the forecast miss was smaller than a half a percentage point. The largest misses come from the distortions from the September 11 
terrorist attacks — hardly a critique of the model.

A close comparison of the results with the EM model estimated over the longer sample shows that less of the growth of M2 is attributed to the equity market variables over the shorter sample and more is attributed to the opportunity cost variable. However, the equity market variables are still statistically significant and large enough not to be discounted.

\section{Conclusions}

In this paper we presented evidence that the fit of a standard money demand model can be improved by including equity market variables. This result should, perhaps, be unsurprising, as equities have become a more important part of household portfolios. The general specification of the Conference Aggregate model still seems appropriate, however the equilibrium portfolio decision can be improved by adding in equity market volatility. We find that increases in the volatility in equity markets tends to increase the equilibrium level of M2 balances.

The short-run specification can be improved by adding stock market variables as well. Revisions to analysts earnings projections appear to have significant explanatory power in the short-run changes in money growth rates. Presumably, changes in earnings expectations reveal changes in the perceived opportunity cost of holding money. Increased earnings expectations tend to suppress the growth as money, presumably as more wealth is allocated towards equities, and less toward money balances.

The historical decomposition of money growth rates into contributions from the driving variables confirms that equity market variables have an economically significant 
impact on the growth of M2. Further, the small amount of out-of-sample forecasting we were able to perform indicates that forecasting can be improved as well by adding equity market variables. While the current research is not a definitive answer in the long history of the money demand literature, it does point to an avenue that is perhaps underappreciated. 


\section{References}

Bomberger, William. "Income, Wealth, and Household Demand for Deposits," American Economic Review 83 (September 1993), 1034-1044.

Duca, John. "Financial Technology Shocks and the Case of the Missing M2," Journal of Money, Credit and Banking 32 (November 2000), 820-839.

Elyasiani, Elyasiani, and Nasseh, Alireza. "The Appropriate Scale Variable in the U.S. Money Demand: An Application of Nonnested Tests of Consumption Versus Income Measures," Journal of Business and Economic Statistics 12 (January 1994), 47-55.

Engle, Robert F, and Granger, Clive. "Co-integration and Error Correction:

Representation, Estimation, and Testing," Econometrica 55 (March 1987), 251-76

Goldfeld, Stephen. “The Case of the Missing Money," Brookings Papers on Economic Activity 1976-3 (1976), 683-730.

Goldfeld, Stephen, and Sichel, Daniel. "The Demand for Money," Handbook of Monetary Economics, Volume 1, Handbooks in Economics, No. 8 (1990), 299-356

Johansen, Soren, and Juselius, Katarina. "Maximum Likelihood Estimation and Inference on Cointegration - with Applications to the Demand for Money." Oxford Bulletin of Economics and Statistics 52 (May 1990), 169-210.

Judd, John and Scadding, John. "The Search for a Stable Money Demand Function: A Survey of the Post-1973 Literature," Journal of Economic Literature 20 (September 1982), 993-1023.

Lown, Cara, Peristiani, Stavros and Robinson, Kenneth. "What was Behind the M2 Breakdown?" Federal Reserve Bank of Dallas Financial Industry Studies Working Paper (February 1999).

Moore, George, Porter, Richard, and Small, David. "Modeling the Disaggregated Demands for M2 and M1: The U.S. Experience in the 1980s," Financial sectors in Open Economies: Empirical analysis and policy issues, Federal Reserve System, Board of Governors, (1990), 21-105.

Orphanides, Athanasios and Porter, Richard. "P* Revisited: Money Based Inflation Forecasts with a Changing Equilibrium Velocity," Board of Governors of the Federal Reserve System, FEDS Working Paper No. 1998-26 (May 1998).

Tobin, James. "A General Equilibrium Approach to Monetary Theory," Journal of Money, Credit and Banking Feb. 1969, v. 1, issue 1, pp. 15-29. 


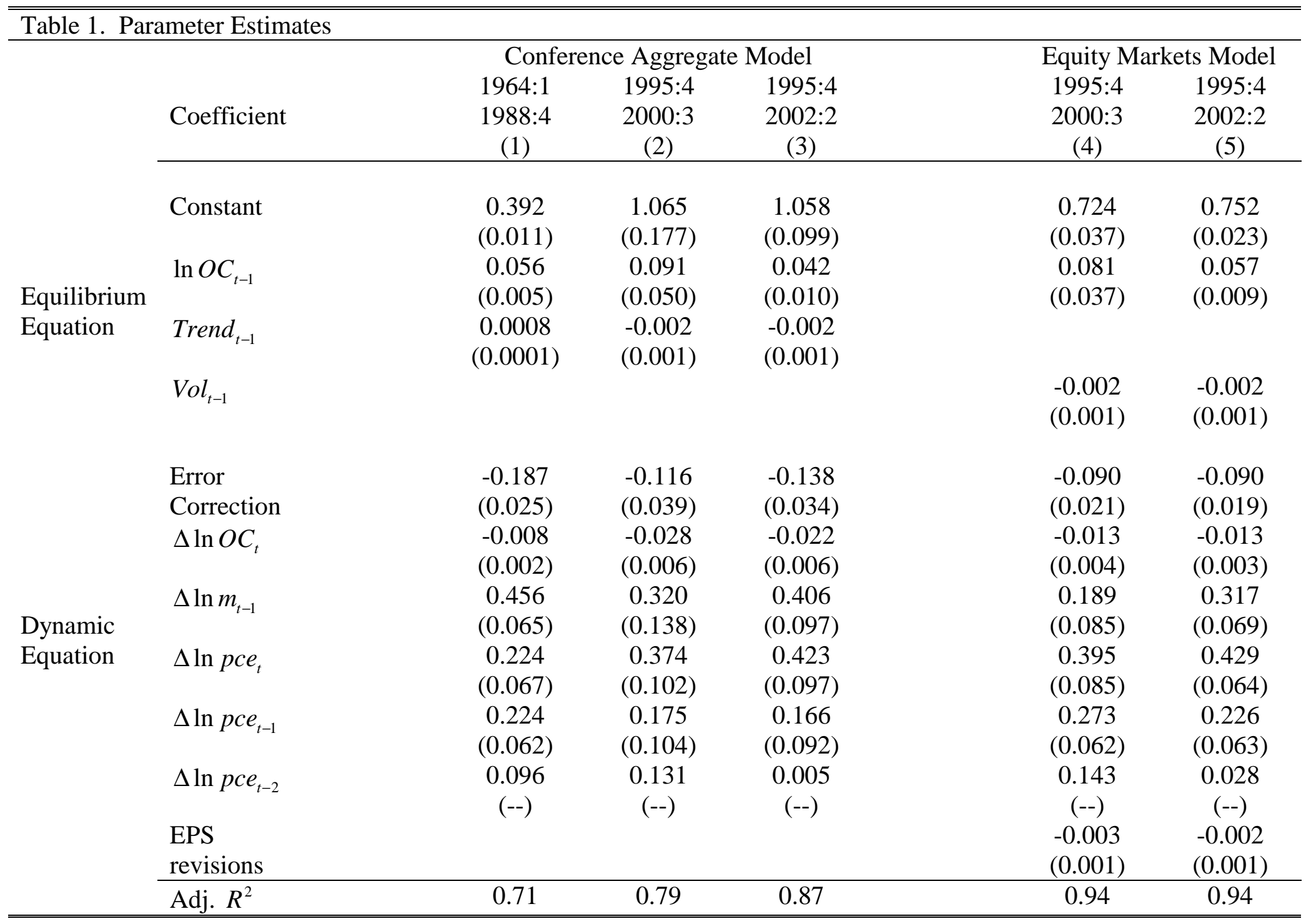




\begin{tabular}{|c|c|c|c|c|c|c|c|}
\hline & $\begin{array}{c}\text { Actual } \\
\text { (1) }\end{array}$ & $\begin{array}{l}\text { Error } \\
\text { (2) }\end{array}$ & $\begin{array}{l}\text { Forecast } \\
\text { (3) }\end{array}$ & $\begin{array}{c}\text { Opp. Cost } \\
\text { (4) }\end{array}$ & $\begin{array}{c}\text { Scale } \\
\text { Variables } \\
(5)\end{array}$ & $\begin{array}{c}\text { EPS } \\
\text { Revisions } \\
(6)\end{array}$ & $\begin{array}{c}\text { Volatility } \\
\text { (7) }\end{array}$ \\
\hline 1994 & 0.6 & 0.7 & -0.1 & -3.0 & 5.4 & -1.5 & -0.3 \\
\hline 1995 & 3.8 & 1.9 & 1.9 & -1.6 & 5.0 & -0.9 & -0.1 \\
\hline 1996 & 4.5 & -0.3 & 4.8 & -0.4 & 5.2 & 0.1 & 0.2 \\
\hline 1997 & 5.6 & -0.6 & 6.2 & -0.2 & 5.9 & -0.2 & 0.8 \\
\hline 1998 & 8.5 & -0.1 & 8.6 & 0.5 & 6.4 & 0.9 & 1.0 \\
\hline 1999 & 6.3 & -0.2 & 6.6 & -0.3 & 6.7 & -0.3 & 0.5 \\
\hline 2000 & 6.1 & 0.1 & 6.0 & -0.9 & 6.8 & 0.0 & 0.1 \\
\hline 2001 & 10.3 & -0.1 & 10.4 & 3.9 & 3.8 & 2.5 & 0.4 \\
\hline
\end{tabular}




\begin{tabular}{|c|c|c|c|c|c|c|c|}
\hline & $\begin{array}{c}\text { Actual } \\
(1) \\
\end{array}$ & $\begin{array}{l}\text { Error } \\
(2) \\
\end{array}$ & $\begin{array}{c}\text { Forecast } \\
\text { (3) }\end{array}$ & $\begin{array}{c}\text { Opp. Cost } \\
(4)\end{array}$ & $\begin{array}{c}\text { Scale } \\
\text { Variable } \\
(5)\end{array}$ & $\begin{array}{c}\text { EPS } \\
\text { Revisions } \\
(6) \\
\end{array}$ & $\begin{array}{c}\text { Volatility } \\
(7)\end{array}$ \\
\hline 2000:01 & 5.9 & 0.1 & 5.8 & -1.3 & 7.9 & -1 & 0.1 \\
\hline 2000:02 & 6 & 0.1 & 5.8 & -1 & 7.2 & -0.6 & 0.2 \\
\hline 2000:03 & 6.1 & 0.4 & 5.7 & -1.1 & 6.5 & 0.1 & 0.2 \\
\hline $2000: 04$ & 6 & -0.3 & 6.3 & -0.8 & 5.4 & 1.8 & -0.1 \\
\hline 2001:01 & 9.7 & -0.3 & 10 & 1.6 & 5.2 & 2.9 & 0.4 \\
\hline 2001:02 & 9.6 & -0.6 & 10.2 & 3.1 & 4.2 & 2.5 & 0.4 \\
\hline 2001:03 & 11 & 3.6 & 7.4 & 2.8 & 2.2 & 2.3 & 0.1 \\
\hline 2001:04 & 9.4 & -3.4 & 12.8 & 6.7 & 3.1 & 2.8 & 0.3 \\
\hline 2002:01 & 5.8 & -0.1 & 5.9 & 3.6 & 3.2 & -1.1 & 0.2 \\
\hline
\end{tabular}




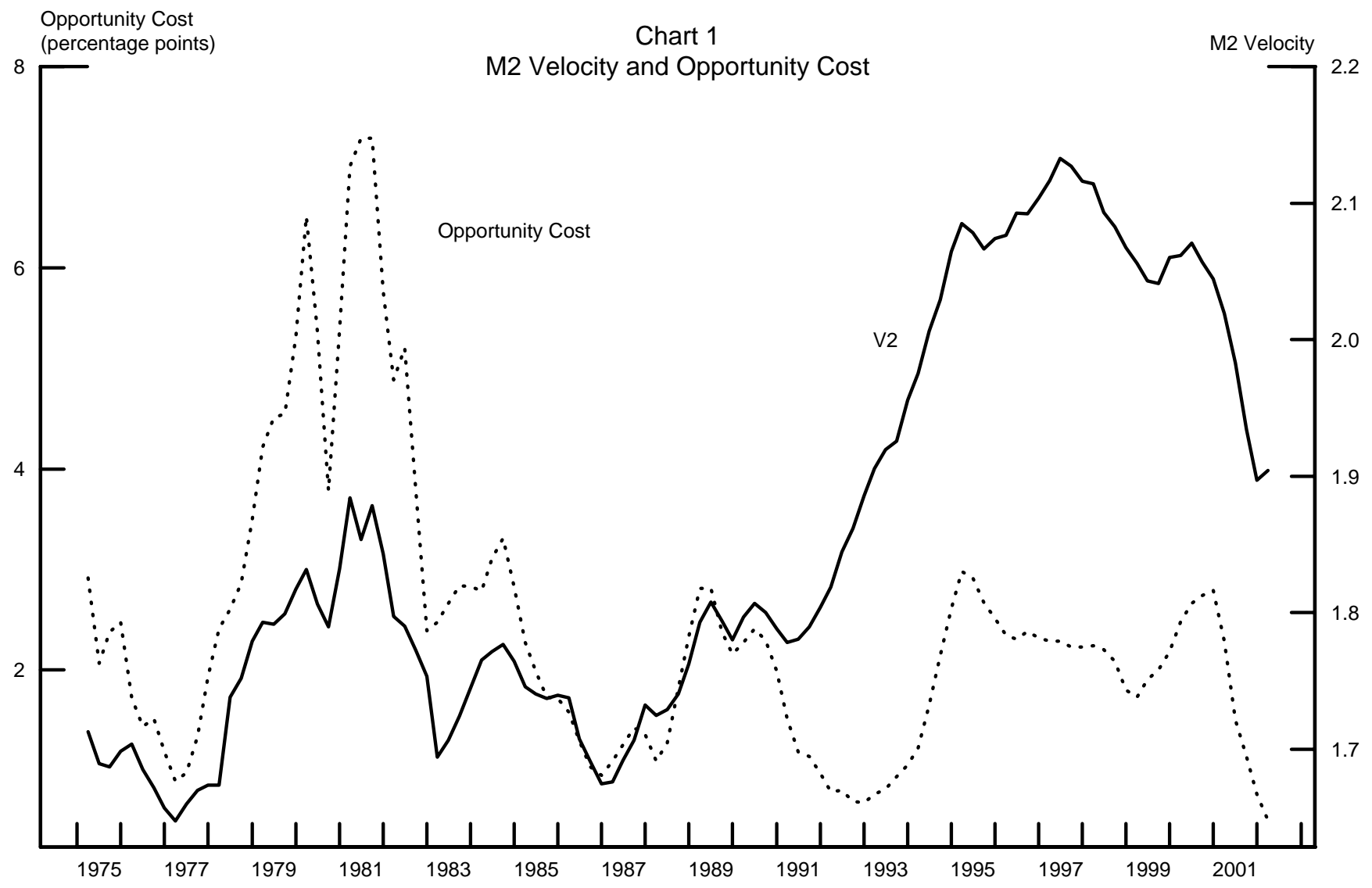



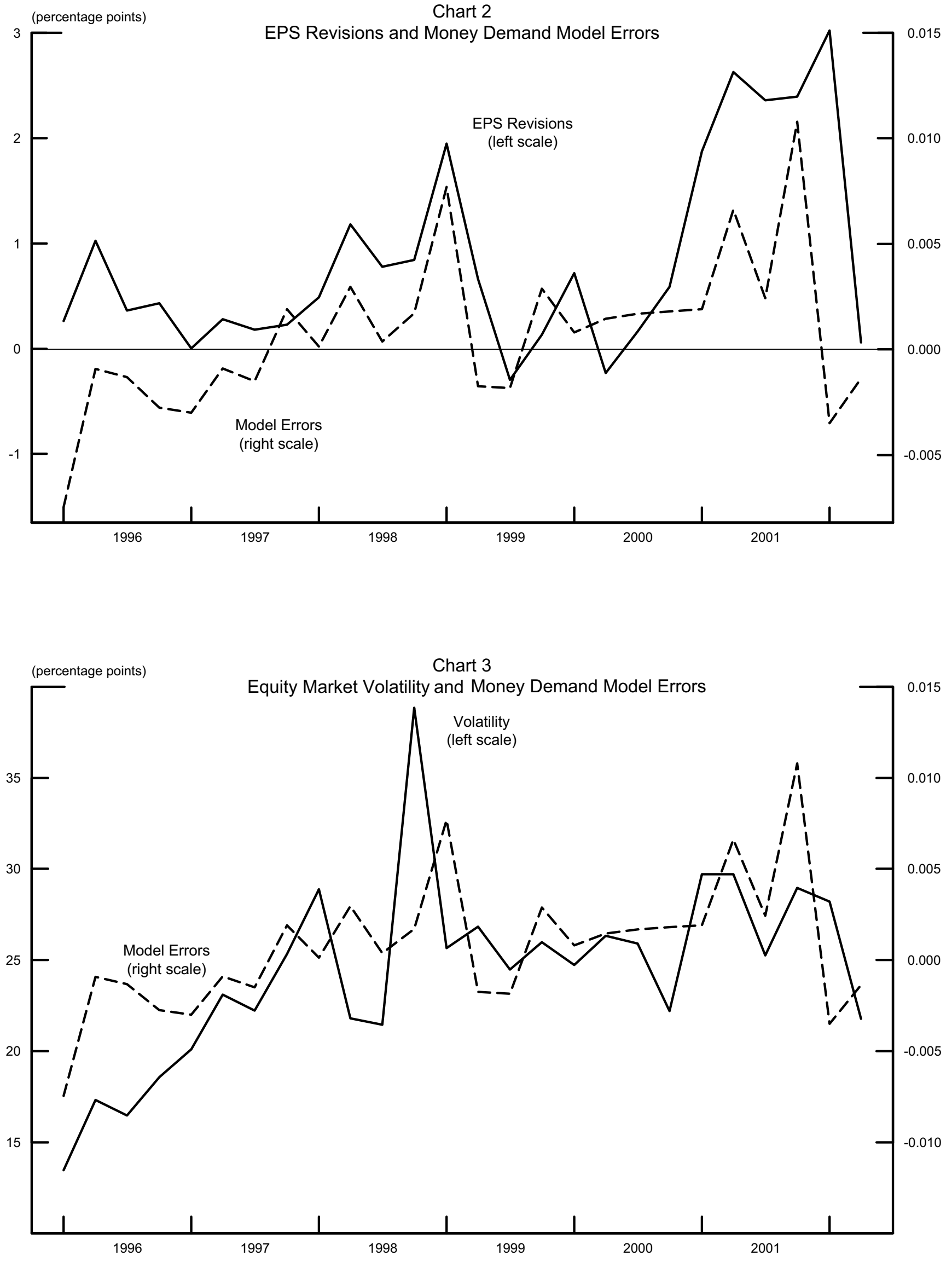